\title{
MEMOIR
}

\section{ARTHUR DIGBY BESANT}

To many of us the news of the death, on 29 April 1960, of Arthur Digby Besant, in his 92nd year, implied not only the loss of an old friend but also the breaking of a link with the past, almost indeed with an era. For long he had seemed so little changed and, until well after his goth birthday, he retained a mental alertness and a youthful readiness, which belied his years, to be interested in current events and especially in the affairs of the Institute of which he was such a devoted member.

He came from a scholarly family. His father, a Wrangler like two of his brothers, was a schoolmaster for a year or two and, after that, a country vicar; his mother was that outstanding personality, Annie Besant. He had a pride in his ancestry which led him to undertake, as a labour of love and with his characteristic industry and care, the compilation of an interesting volume, The Besant Pedigree, published in 1930. There he tells how his birth, on 16 January 1869 , 'checked for a time my mother's literary career' and how his father 'precise and methodical as ever' recorded in his diary all the relevant domestic details. It is clear from this family history that two distinguished members held very special places in his heart: his mother and his uncle, Sir Walter Besant, for whose constant help and encouragement he expresses his unbounded affection and admiration.

He married in 1894 , and two years later a son, Digby, was born who, to Besant's great sorrow, lived only a few months. Later, two daughters were born, the younger of whom, Sylvia, survives him. She was a frequent visitor at her father's home in Hampstead, a great help and comfort to him in his later years, and was with him at the end.

The early years of Besant's education took place in small private schools near his father's vicarage at Sibsey in Lincolnshire and at Boston Grammar School. Then, at the age of twelve, he entered Portsmouth Grammar School where he stayed for six years and, whilst there, passed the London Intermediate B.A. Examination. Upon leaving school, he took up residence in a hostel attached to University College, London, and obtained his B.A. degree in 1889 , at the age of 20 . He obviously enjoyed these undergraduate days for, he writes: 'Many firm friendships were formed and I look upon these two years as amongst the most useful and pleasant of my life.'

Those firm friendships were strengthened and new friendships formed in the course of the close association which he maintained with his old college throughout the rest of his life. In 1924, he was elected a Fellow of the College, an honour which gave him lasting pleasure and satisfaction. Six years earlier he had been invited to join the College Committee, upon which he served for 33 years holding, for a long period, the office of Treasurer and being appointed, from 1944 to 1948, the College's representative upon the Senate of the University of London. After his retirement from active Committee work, in I95I, he remained a member of the Council of the Friends of University College until his death, and in that capacity did much to foster the improvement of amenities for students, for whose interests he always showed especial concern.

When Besant's own student days ended, in 1889 , the problem of the choice of 
a career arose and was solved, as in the case of some other actuaries in those days, almost by chance. A previous pupil of one of his Wrangler uncles was an actuary and an interview with him set the necessary train of events in motion. Besant lost no time in joining the Institute, being nominated by $\mathrm{Dr} T$. B. Sprague, and, shortly afterwards, learned that temporary work was available at the 'Clerical, Medical and General'. His application for employment was accepted and so began a happy association with the 'Clerical' which was to last for nearly seventy years.

His rise in the Society's service was rapid. At age 29 he was appointed assistant actuary and at age 37 he became the principal officer, a position which he held for twenty-seven years until his retirement in 1933. For the first twenty of those years he lived above the Society's Head Office at 15 St James's Square and many of his friends will have happy memories of evenings spent in those attractive surroundings with Besant acting, as he delighted to do, as the genial host. Upon his retirement he was elected to a seat on the Board of the Society, a position which he retained until 1957, acting for the last nine years as a Deputy Chairman.

This exceptionally long association enabled him to claim a personal link with the formation of the 'Clerical, Medical' in 1824 , in that when he started work as a junior, in 1889 , the Society's first junior was still an active Director. When the Society attained its Centenary, in I 924, Besant was invited to write the history of its first hundred years. This was a task after his own heart and he delved into old Minute Books and records with the greatest thoroughness and enjoyment. The result was a charming little book, 'Our Centenary', in which he has left a fitting monument to his devotion to the Society and regard for those traditions which he did so much, during a life-time of service, to maintain.

From his staff he commanded a high degree of respect and affection and none could fail to admire that old-world courtesy which was so natural to him. Unfortunately, not all of his colleagues could live up to his exacting standard of detailed accuracy, or match his remarkable memory. But if their lapses led to occasional moments of exasperation, these were rapidly forgotten, their recollection being obliterated by lasting memories of frequent acts of kindness and generosity. In and out of the office, Besant was very fond of writing. He was equally happy in sketching the framework of a first draft, or in debating, at final proof stage, the aptness of a phrase or the merit of a comma. His industry, energy and complete absorption in any task which he undertook were a constant example to colleagues of all degrees of seniority.

These same qualities were placed, with equal zest, at the disposal of the Institute which Besant speedily grew to recognize as one more welcome field of service in which he could devote his energies to any task that might be entrusted to him. This readiness to serve, needing in his case no encouragement, derived added zeal from the fact that he was coached for his examinations, which he completed in 1895 , by Sir George Hardy. Recalling, some sixty years after, his memories of those days, Besant wrote a glowing tribute to ' G.F.' towards whom, he said, his feelings were those of affection and veneration, mixed with gratitude and admiration for the friendly and intimate way in which he followed the subsequent careers of his students.

The Institute certainly delighted Besant by keeping him busy and electing him, in due course, to all its principal posts. After a spell of duty as an Examiner he was Honorary Secretary, twice a Librarian, Vice-President, Treasurer and, in 1924-26, President, serving, in all, for 27 years on the Council. He made 
numerous contributions to the fournal and, apart from his interesting Presidential Address, was the author of two Papers. The first, submitted in 19 I 4 after a visit to Canada, dealt with Canadian Mortgages as a ficld for the investment of the funds of British Life Assurance Companies, and the second, in 1923, with some actuarial aspects of the Local Government and Other Officers' Superannuation Act, 1922.

During the early months of his Presidency, Besant found himself exceptionally busy for, in addition to his appointment as a member of the Royal Commission on National Health Insurance, he was also serving his second year as Chairman of the Life Offices' Association. This latter post took up much of his time and energy, because the Association was in the throes of producing evidence and voluminous memoranda for the consideration of the Departmental Committee appointed to enquire into the desirability of amending the 1909 Assurance Companies Act. He revelled in all these activities, especially in his Presidency, but mildly deplored the fact that they should all have arrived at once. It was a disappointment to him, although not really surprising, that at this stage his health, normally excellent, faltered and in the spring of 1925 he was compelled, on his doctor's advice, to give up work for a time. Happily, after a rest of two or three months, the signs of strain disappeared and, apparently, no ill effects resulted. Incidentally, his almost unbroken record of good health might be regarded as somewhat remarkable as, apart from his annual Swiss holidays from which he always returned refreshed and rejuvenated, he took practically no regular physical exercise.

How much these holidays meant to him is clear from one of the rare references to himself in his record of the family. He writes, 'In 1898 came the first visit to Switzerland and my introduction to the snow mountains. The fascination that they exert is overwhelming ; it cannot be explained, it can only be felt.' His last visit, which he much enjoyed, was in I959. His favourite haunt was Saas Fee with its 'endless choice of walks through the pine woods, or along the mountain paths which lead upwards to the climbers' paradise beyond'. A recent visitor to a hotel there had only to salute Besant's photograph, which occupied a place of honour in the hall, to be whisked away by the manageress and shown, as a great favour, her treasured collection of souvenirs in which, at the end of each stay, he had conveyed to her his thanks in verse. The pleasure that he derived from composing and declaiming his verses is well-known to his friends and especially to fellow members of the actuarial dining clubs whose meetings he enjoyed so much.

Besant was one of a group of five actuaries who, in 1903 , founded the Gallio Club and he was elected to the Actuaries' Club a year later. His keen and enduring interest in both Clubs was shown by his regular attendance. Especially after his retirement, he never lost an opportunity of kecping in touch with old friends and making the acquaintance of the 'youngsters' who were coming along. He served as Chairman of each Club, became in time its senior member, and was awarded, in 1959 , by the Actuaries' Club, the unique status of Honorary Member Emeritus. Both Clubs entertained him, as their guest of honour, at special dinners held to commemorate his attainment of age 90 , friendly gestures which he greatly appreciated. In 1953, as the last survivor of the founder members, he prepared an attractive little history of the Gallio Club's first fifty years of existence. Throughout its pages one can sense his pride at having been in at the birth of the Club and his pleasure at having lived to see it fulfilling so successfully, to quote his own words, 'its original purpose of providing friendship and good fellowship'. 
Who's Who, at one time, listed his hobbies as philately, mountain walking and billiards. To the first he devoted, for years, much time and enthusiasm but of the last he confessed that his skill was in inverse proportion to his fondness for the game. Possibly he might have added one further confession, that his favourite hobbies concerned things not far removed from work.

Throughout his life, Besant gave freely of his best to any institution that offered, what he most desired, opportunities for service. In return he hoped to receive the thrill of office, a finger in the pie of administrative responsibility and the goodwill and esteem of colleagues and friends. These hopes were realized, in no small measure, in the case of his old college and in his business career, but it was the Institute that gained pride of place in his heart by granting him his highest ambition, the Presidency. His feelings at entering upon it were emotions of happiness and humility.

These are his own words. No others could better describe the spirit in which he served.

A. H. ROWELL. 